\title{
Études/Inuit/Studies
}

\section{Labrador Inuit and their arrow shafts}

\section{Les Inuit du Labrador et leurs hampes de flèches}

\section{Greg Mitchell}

Volume 39, numéro 1, 2015

Les Inuit au Labrador méridional

The Inuit in southern Labrador

URI : https://id.erudit.org/iderudit/1036082ar

DOI : https://doi.org/10.7202/1036082ar

Aller au sommaire du numéro

\section{Éditeur(s)}

Association Inuksiutiit Katimajiit Inc.

Centre interuniversitaire d'études et de recherches autochtones (CIÉRA)

\section{ISSN}

0701-1008 (imprimé)

1708-5268 (numérique)

Découvrir la revue

Citer cet article

Mitchell, G. (2015). Labrador Inuit and their arrow shafts. Études/Inuit/Studies, 39(1), 165-188. https://doi.org/10.7202/1036082ar

\section{Résumé de l'article}

Du XVI ${ }^{\mathrm{e}}$ au XVIII ${ }^{\mathrm{e}}$ siècle, il semble que les Inuit du Labrador aient prisé les bois tendres des troncs de conifères pour fabriquer les flèches de différentes tailles qu'ils utilisaient à la chasse et à la guerre. L'examen au microscope des hampes de flèches inuit du site Twin Island 3 (EkBc-07) de Red Bay montre que l'espèce de prédilection pour cette fonction, au XVI ${ }^{\mathrm{e}}$ siècle, était le sapin baumier, Abies balsamea. Le sapin baumier pousse en abondance dans les baies très échancrées du Labrador méridional et les Inuit pouvaient facilement s'en procurer. Cependant, des sources d'archives mentionnent qu'au XVIII ${ }^{\mathrm{e}}$ siècle, les Inuit du Labrador désiraient d'autres espèces de bois tendres pour leurs flèches, bois qui ne poussaient que sur l'île de Terre-Neuve. J'émets l'hypothèse que les espèces recherchées étaient l'une ou l'autre des deux espèces de pins qui poussent au centre de Terre-Neuve (Pinus strobus ou Pinus resinosa), voire les deux. Le fait qu'ils se soient procurés du bois de pin à Terre-Neuve ajoute une nouvelle dimension à la mobilité et aux schémas commerciaux des Inuit dans le Labrador méridional. Les conflits avec les Européens au cours du $\mathrm{XVI}^{\mathrm{e}}$ siècle et jusqu'au XVIII ${ }^{\mathrm{e}}$ siècle dans le détroit de Belle-Isle et le Petit-Nord (dans la Grande Péninsule du Nord de Terre-Neuve) pourraient en partie avoir résulté d'une perturbation de ces schémas de déplacement et de récolte. Je suggère que les objets en fer et les chaloupes en bois du sud du Labrador et du nord de Terre-Neuve n'étaient pas les seules marchandises «méridionales» que cherchaient à se procurer les Inuit durant les premiers stades de l'occupation européenne; le bois de pin du centre de Terre-Neuve était également important pour la fabrication des hampes de flèches.
Ce document est protégé par la loi sur le droit d'auteur. L'utilisation des services d'Érudit (y compris la reproduction) est assujettie à sa politique d'utilisation que vous pouvez consulter en ligne.

https://apropos.erudit.org/fr/usagers/politique-dutilisation/ 


\title{
Labrador Inuit and their arrow shafts
}

\section{Greg Mitchell*}

\section{Résumé: Les Inuit du Labrador et leurs hampes de flèches}

Du XVI ${ }^{\mathrm{e}}$ au XVIII ${ }^{\mathrm{e}}$ siècle, il semble que les Inuit du Labrador aient prisé les bois tendres des troncs de conifères pour fabriquer les flèches de différentes tailles qu'ils utilisaient à la chasse et à la guerre. L'examen au microscope des hampes de flèches inuit du site Twin Island 3 (EkBc-07) de Red Bay montre que l'espèce de prédilection pour cette fonction, au $\mathrm{XVI}^{\mathrm{e}}$ siècle, était le sapin baumier, Abies balsamea. Le sapin baumier pousse en abondance dans les baies très échancrées du Labrador méridional et les Inuit pouvaient facilement s'en procurer. Cependant, des sources d'archives mentionnent qu'au XVIII ${ }^{\mathrm{e}}$ siècle, les Inuit du Labrador désiraient d'autres espèces de bois tendres pour leurs flèches, bois qui ne poussaient que sur l'île de Terre-Neuve. J'émets l'hypothèse que les espèces recherchées étaient l'une ou l'autre des deux espèces de pins qui poussent au centre de Terre-Neuve (Pinus strobus ou Pinus resinosa), voire les deux. Le fait qu'ils se soient procurés du bois de pin à Terre-Neuve ajoute une nouvelle dimension à la mobilité et aux schémas commerciaux des Inuit dans le Labrador méridional. Les conflits avec les Européens au cours du XVI ${ }^{\mathrm{e}}$ siècle et jusqu'au XVIII ${ }^{\mathrm{e}}$ siècle dans le détroit de Belle-Isle et le Petit-Nord (dans la Grande Péninsule du Nord de Terre-Neuve) pourraient en partie avoir résulté d'une perturbation de ces schémas de déplacement et de récolte. Je suggère que les objets en fer et les chaloupes en bois du sud du Labrador et du nord de Terre-Neuve n'étaient pas les seules marchandises «méridionales» que cherchaient à se procurer les Inuit durant les premiers stades de l'occupation européenne; le bois de pin du centre de Terre-Neuve était également important pour la fabrication des hampes de flèches.

\begin{abstract}
Labrador Inuit and their arrow shafts
From the 16th to 18 th centuries, Labrador Inuit seem to have valued softwoods (from coniferous tree boles) for the manufacture of arrows and darts used in hunting and warfare. Microscopic examination of Inuit arrow shafts from the Twin Island 3 site (EkBc-07) in Red Bay shows that balsam fir (Abies balsamea) was the preferred species for these purposes in the 16th century. Balsam fir is found in abundance in the inner bays of southern Labrador and was easily accessible to Inuit. However, archival sources indicate that by the 18th century Labrador Inuit desired another species of softwood for arrow and dart shafts, one that grew only on the island of Newfoundland. I propose that the sought-after species was one, or both, of the two pine species growing in central Newfoundland (Pinus strobus or Pinus resinosa). Procurement of pine wood from Newfoundland would add another dimension to the established mobility and trading patterns of Inuit in southern Labrador. Conflicts with Europeans during the 16th through 18th centuries in the Strait of Belle Isle and the Petit Nord (on Newfoundland's Great Northern Peninsula) may, in part, have been a result of the disruption in these travel and harvesting patterns. I suggest that iron products and wooden shallops (boats) from southern Labrador and
\end{abstract}

* NunatuKavut Community Council, P.O. Box 3924, RR \# 2, Corner Brook, Newfoundland and Labrador A2H 6B9, Canada.gmitchell@xplornet.com 
northern Newfoundland were not the only "southern" commodities actively sought by Inuit during the early stages of European occupation; central Newfoundland's pine wood was also important for manufacture of arrow shafts.

\section{Introduction}

Over the past 40 years or so, much has been written about the ancestors of the Inuit, the Thule people, who migrated into and along the Atlantic coast of Labrador (e.g., Jordan and Kaplan 1980: 38; Kaplan 1980: 648, 2012: 16; Whitridge 2012: 4456). Progressive movements and settlement patterns of historic Inuit ${ }^{1}$ from northern Labrador during the 15th and 16th centuries into the areas of southern Labrador, the present-day Quebec North Shore, and the island of Newfoundland have come under scrutiny by scholars (Fitzhugh et al. 2011; Kelvin and Rankin 2014; Kennedy 2009; Martijn 2009: 67-89; Murphy and Rankin 2014; Pope, this volume; Ramsden and Rankin 2013; Rankin 2013, 2014; Rankin et al. 2012; Stopp 2002). McGhee (2009: 161) has suggested that the Thule quest for iron was a primary driver of migrations across and throughout the Arctic. Into the 17th and 18th centuries, Labrador Inuit acquired prized European iron products and wooden boats (shallops) ${ }^{2}$ by stealing and trade.

Furthermore, it has recently been established that Inuit presence in southern Labrador included year-round activities and was of a permanent nature (Rankin 2014: 39; Stopp 2002: 96). Historic Inuit resource procurements, at least as evidenced by cache pits (Stopp 2014: 5) and by some archival evidence, ranged as far south as Notre Dame Bay on the northeast coast of Newfoundland (Marshall 1996: 54-55; Martijn 2009: 85) (Figure 1). Whether such a range for historic Inuit was in place prior to or after European colonization of the area is yet to be established.

In Alaska and the western Canadian Arctic, the Thule were "big wood users," and those migrating across the Canadian Arctic Archipelago would have been preoccupied with acquiring wood resources (Alix 2009b: 149). The Thule moving into Labrador would have had similar needs and desires. Having come from a culture of wood use in the western regions and been accustomed to using driftwood during movements across the North, migrants to Labrador may well have been in search of specific types of wood for desired end-uses. The Thule people came to Labrador from the Central and High Arctic at the beginning of the Little Ice Age and had moved south due, in part, to

1 Historic Inuit refers to the descendants of the Thule who had acquired some European material culture and had often adapted those articles to suit lifestyle needs. Iron was the most valued European material, however. Other items, such as tiles, utensils, boats, ropes, etc., were used for various purposes.

Inuit valued wooden boats, as they were more maintenance-free and easier for upkeep than the skincovered traditional umiak, the Inuit women's boat used to transport large numbers of people (women and children) and usually propelled by women. The singly occupied kayak was used primarily by men.

166/G. MITCHELL 
deteriorating resource harvesting opportunities (Whitridge 2012: 50). In Labrador, they likely encountered trees at or near the present-day treeline of Napaktok Bay, at approximately 58 degrees latitude (Elliott and Short 1979: 201). The encounter would have brought about both "excitement and pause" (Kaplan 2012: 35)-excitement because they now had growing trees that could be put to desired uses, and pause because the dense forests presented a likelihood of spiritual dangers (ibid: 36; see also Alix 2012: 16).

In locations where it could be found, High Arctic driftwood made up the primary source of raw materials to be utilized in housing structures, boats, sleds, utensils, and weapons (Kaplan 2012: 35). The literature indicates that a number of pine species were present in driftwood accumulations in the Western, Central, and High Arctic (Dyke et al. 1997: 7; Hellman et al. 2013: 5). Archaeological investigations show a number of uses for pine wood in these regions (Alix 2009b: 152; Alix et al. 2012: 98-101; Gronnow 2013: 27; Sutherland 1999). Inuit would have been familiar with the qualities of pine wood as arrow-shaft material before entering Labrador. The value of pine wood for arrow shafts is its cleavability, straightness, light weight, and strength-qualities well known to archers and experts (Alix 2009a: 189; Alix et al. 2012: 103; Mason 1894; Tim Rast, pers. comm. 2014).

So far, no pine species found on the island of Newfoundland (Pinus strobus and Pinus resinosa) have been reported in the major collections of driftwood from the Arctic. However, differentiation between species of pine by anatomical methods is difficult at best. For example, there is no way to distinguish microscopically between Pinus strobus, a North American species, and Pinus cembra, a Siberian species (Alix 2009a: 191). Furthermore, primarily as a result of recent logging, pine today represents a major component (39.3\%) of High Arctic driftwood, and almost all of this component is made up of Pinus sylvestris (Hellman et al. 2013: 5), an introduced species in North America (Fernald 1950: 56). Thus, North America is not likely a source for Pinus sylvestris among archaeological specimens. All in all, it would be premature to draw definite conclusions about some pine species at archaeological sites in the Far North where driftwood is prevalent.

In this paper, I will present historical and archaeological evidence on the types of wood used by the Labrador Inuit to make arrow shafts. I will argue that iron products and wooden shallops from southern Labrador and northern Newfoundland were not the only "southern" commodities actively sought by Inuit during the early stages of European occupation. Pine wood from central Newfoundland was also important for manufacture of arrow shafts.

\section{Labrador Inuit skills in the use of "arrows and darts"}

Arrows and darts were used by Labrador Inuit to hunt various species of mammals and birds and were propelled either by a strung bow or by a throwing board (atlatl) (Cartwright 1792: 139, 238). These weapons were also used for various warfare tactics 
(Marshall 1996: 53; Mitchell 2013: 322). Charles Martijn describes Inuit skills in the following manner:

For their part, the Inuit were fearsome archers, skilled in stalking land game such as caribou, and bringing them down with accurate volleys of arrows. They also knew how to hunt sea game from their kayaks by deftly casting darts with throwing boards. Similar tactics were employed against fishermen along the Northern Peninsula [the Petit Nord]. Hiding out until cod crews had split up to engage in daily tasks, they [Inuit] would ambush them on land, or swiftly surround and attack fishing shallops or even small vessels in coastal waters with their native watercraft (Martijn 2009: 71).

In a footnote, Martijn describes various incidents in central Labrador where Inuit attacked crew members of European ships using bows and arrows during the 16th through 18 th centuries.

Up to the late 18th century, when Inuit were able to obtain firearms (Rollmann 2011: 5), the importance of straight, light, and strong arrows and copious quantities of them should not be understated. Straight and true arrow shafts were essential in the armed conflicts between Inuit and Europeans during the 16th through 18th centuries (Martijn 2009: 71-78). It was their primary means of both attack and defence. As recently outlined by Crompton (2014), in the early 18th century, Pierre Constantin and his employees often found themselves at the receiving end of the Inuit arrows,

During the month of September [1719], the Inuit had frequently been sighted in and around Red Bay. Over one day and into the night, the Inuit were said to have cried out and shouted making the overwintering crew men nervous. On the morning of September 16th, a group of Inuit expressed their desire to trade at a point near the water. Three of the crewmen gathered firearms, and went to meet the Inuit, leaving the fourth man behind in the dwelling to keep watch. Distracted by their negotiations, the three Frenchmen by the waterfront did not notice four Inuit men hidden in nearby woods. The Inuit emerged from the woods with bows drawn. The man in the dwelling shouted an alarm to his compatriots, who immediately stood up to see what the problem was. While their attention was directed towards the ocean, the Inuit exited the woods and cut off the French men's route of escape. None of the Frenchmen had time to raise their firearms before being shot with multiple arrows (Crompton 2014: 110-111).

This incident resulted in the deaths of the three individuals. In the recorded 38 armed conflicts during 150 years of guerilla warfare between Inuit and Europeans (Martijn 2009: 72, 73; Mitchell 2013: 322; Pope, this volume), the primary projectile used by Inuit was the wooden shafted arrow. In and around 1752, southern Inuit attacked and killed 29 French fishermen in the Cape Onion area of Newfoundland's Great Northern Peninsula (Lanteigne 2014: 3). Inuit attacked and killed 13 English fishermen and wounded another 14 men in a single incident, at nearby Quirpon, nine years later using wooden arrows (Anonymous 1761). One can predict that the likelihood of recovering arrows following a conflict would have been very low, unlike the likelihood of recovering arrows shot during a hunt. Such attacks required a good arsenal of arrows. The loss of these projectiles in combat consequently led to a very high demand for new arrow shafts in the mid-18th century. 
French fishermen were strictly forbidden to sell, barter, or trade firearms with Inuit (Martijn 2009: 73), and firearms did not really come into general use among Inuit in southern Labrador until the time of George Cartwright in 1771 (Stopp 2008: 178) and among Inuit in northern Labrador until the Moravians' decision in 1785 to sell them guns (Rollmann 2011: 13). By 1798, according to Captain Ambrose Crofton (1798: 34) from Temple Bay, Labrador, in a report to Vice-Admiral Waldegrave, the Inuit had "laid aside the Bow and Arrow."

\section{Beothuk uses of pine wood}

Pine for arrows was used extensively on the island of Newfoundland in historic times. The Beothuk ${ }^{3}$ of northeast Newfoundland appear to have preferred pine for arrow shafts because its light weight, cleavability, and straight grain made it quick and easy to construct rough arrow blanks (Tim Rast, pers. comm. 2014). Pine wood was readily available in their local area (Damman 1983: 76). Beothuk used bows and arrows for hunting and during their many conflicts with Europeans, especially since they never did acquire European firearms (Marshall 1996: 95-103). Following the incursion of Europeans into the Northwest Atlantic, both Inuit and Beothuk relied heavily on their weapons at hand to protect themselves, and any arsenal had to include lightweight and straight arrow shafts.

In describing the habits and material culture of the Beothuk, George Cartwright tells us that, "The arrows are made of Weymouth pine; they are slender, light, perfectly straight and about three feet long" (Cartwright 1792: 10). The "Weymouth pine" he describes, named as such following its introduction to England in 1620 by George Weymouth, is the eastern white pine (Pinus strobus). John Cartwright, who led an expedition to central Newfoundland in search of the Beothuk in 1768, accompanied by his brother George, had a similar description of the Beothuk arrows, "The arrow is made of well-seasoned pine, slender, light and perfectly straight" (Cartwright 1969[1826]: 313). In at least one report, "settlers (in the Bay of Exploits) found a store of about five hundred arrows in a mamateek" (Marshall 1996: 316). Was this large number of arrows prepared for use by the Beothuk alone or for some kind of interindigenous trade?

\section{Evidence of pinewood procurement in Newfoundland}

In the 1750s, transient French fishermen at Quirpon (northern Newfoundland) began to enjoy a brief period of peace with Inuit travelling to and from Newfoundland, thanks to an agreement negotiated by a Captain Galiot of St. Malo (Lysaght 1971: 188;

3 Amerindian group occupying parts of the island of Newfoundland at the time of "discovery" by Europeans (late 15th century) and surviving to the early 19th century.

4 Generic term for a Beothuk house of various shapes and sizes and made up of various materials depending on season of use. 
Martijn 2009: 79). By the Treaty of Paris in 1763, Labrador was ceded to Great Britain, and the new governor, Sir Hugh Palliser, sought to put a complete halt to Inuit/French trade in northern Newfoundland by making peace with the Inuit and refusing them entry to Newfoundland (where the French had fishing rights), mostly by gentle persuasion (Lysaght 1971: 207-212) but, in some cases, by the force of British guns (Irving 1772).

In the summer of 1765 , Palliser met with a group of approximately 500 Inuit at Chateau Bay in southern Labrador (Figure 1). In an effort to achieve peace, end the "guerilla warfare" (Pope, this volume), and stabilize the British ship fishery, he employed several Moravian missionaries who were fluent in Inuttitut as interpreters. The Moravians were instructed to spend time with the Inuit and were given a number of vetted questions. Over a month-long period (August 18th to September 21st), the various Moravians and British Navy members met with what appear to have been three different groups of Inuit (Lysaght 1971: 197-212; Palliser 1765: 225-245). From the original accounts given in colonial records, most encounters eventually led to a discussion of Inuit travel to Newfoundland. For example, on September 5th,

\begin{abstract}
We [Moravians] had orders to persuade them [Inuit] not to go to Newfoundland and assured them they would not be secure of their lives there as they are here [Chateau Bay]; but they sayd [sic] they could not avoid going, the wood of which they made their Arrows and Darts grew there and not in their Country and desired as we were their good Friends we might not hinder them (Lysaght 1971: 207).
\end{abstract}

And again on September 7th,

[...] these [Inuit] waited an opportunity of a fair Wind to cross over to Newfoundland. [...] We answered no and advised as their good friends not to go to Newfoundland, but they said they must go to procure wood for their Darts, etc. and desired us to entreat the Captain and that he might do them no hurt on their passage [to Newfoundland] (ibid. 208).

A week later, on September 13th, the Inuit were still insistent on going to Newfoundland, "The Indians [Inuit] inquired again about Quirpont [sic] and the people there, if we knew them? Answer no! Do you think we may venture to go there? Answer no we would by no means advise you to it" (Lysaght 1971: 197-212; Palliser 1765: 225-245).

By September 20th, against all advice from the Moravians, they insisted on going, "[...] Indians, whom they found in their Boats with all their baggage at the mouth of the bay on their way to Newfoundland." The next day, after such insistence, the Inuit went over to the island of Newfoundland, "When he [Jens Haven] returned on board Sir Thomas [Adams] sent for us and proposed as the Indians were now gone he would send the shallop with two of us to Croque [Newfoundland] to the "Lark" to speak with the Indians [Inuit] in Newfoundland" (Palliser 1765: 225-245). 
These visits to Newfoundland continued into later years. On August 4, 1770 during a conversation with two Inuit (Mikak and Tuglavia), the Moravian missionary Christian Drachardt

[...] reminded Mikak of the 1765 conversation with Palliser where Inuit had been asked not to come anymore to "Ikeremiklua" [also Ikeremeklua], i.e. Newfoundland. He states they can get wood in Newfoundland but no European boats. Mikak tells Drachardt that Lucas [Francis] has told her this many times, and she made it known to the Inuit last winter [1669/1770] and was going to remind them of it (Drachardt 1770, translation by Hans Rollmann).

Some have identified the type of wood mentioned in the above passages as "white spruce" (Taylor 1972: 139). It must be understood that the word describing the species was given to the scribe (Drachardt) in Inuttitut, written in German and, in some records, further translated into English. It is possible that the actual species was lost in translation, or never really understood in the first place. Two local spruce species (Picea glauca and Picea mariana) are abundant in Labrador and, consequently, do not qualify as allochthonous. White spruce (Picea glauca) is suitable for manufacture of arrow shafts and makes up part of the forests of the inner bays of coastal Labrador, and its close relative, balsam fir (Abies balsamea), is similarly available in Labrador. The evidence, presented below, indicates that Inuit utilized this species for manufacture of arrow shafts in the 16th century.

The above statements were made in Labrador (Chateau Bay), approximately 90 nautical miles from the nearest stands of pine, on the Baie Verte Peninsula on the Newfoundland coast. This particular location was known to the French in the 17th century as "Baie de Pin" ('Bay of Pine') (Reynolds 1786: 39). Bay of Pine was located between Fleur de Lys (where a Dorset soapstone quarry is located) and Paquet (now called Ming's Bight). Red pine was certainly harvested in this area of Newfoundland for French shipbuilding and, during the 18th century, it was claimed that this harvest curtailed the purchase of pine from Russia and Norway (Anonymous 1762). It is well known that the French carried out closely guarded trade with Inuit (Kennedy 2009; 30; Martijn 2009: 75), and such trade could have included bartering in pine wood for Inuit arrow shafts.

To gain some real understanding of what, today, can be considered errors in the naming of tree species, we must consider the context of the recorders (Moravian missionaries) as they conducted their business. I would suggest that interest in and knowledge of botany were not their strong suits. In fact, intellectual knowledge of plant taxonomy, worldwide, was in its infancy. In 1765, one of their contemporaries was Carolus Linnaeus (1707-1778), the Swedish physician, botanist, and father of modern taxonomy (Campbell and Reece 2005: 439). Linnaeus published his binomial system of plant nomenclature in his Species Plantarum only 12 years before the events at Chateau Bay in 1765. Up to that time, and still today, local and very general terms were used to describe any particular species. As Merritt Lyndon Fernald pointed out in his preface to Gray's Manual of Botany, 
An effort has been made [in the manual] to record the colloquial names under which the more conspicuous plants are known by the layman. These names are, of course very variable and often very local, while such a name as "Mayflower" is used in so many senses as to be essentially meaningless outside restricted areas (Fernald 1970: x).

Were the terms "spruce" and "pine" used similarly in the latter part of the 18th century? Pinaceae is the family to which Linnaeus assigned the junipers, the hemlocks, the spruces and, of course, the pines, in addition to several other genera (Fernald 1970: 52). That "category" of plants is still very much in use today (ibid.: 52-60). It is understandable that Moravian missionaries were, from our perspective in the $21 \mathrm{st}$ century, possibly misnaming plants at the species level, as we identify them today. For these reasons, what may very well have been "pine" ended up being translated or described as "spruce."

Furthermore, Drachardt (the primary interpreter) learned his Inuttitut in Greenland, where there were almost no trees, ${ }^{5}$ and could easily have made an error. In the presentday Labrador Inuttitut lexicon, I could find no word for pine, but the word for pine and spruce cones (lumped together) is kimminguak (Smart Labrador Initiative 2004). In 1765, Inuit may also have been lumping species together and, in turn, misunderstood by the interpreters. Given this and all the other evidence, it appears that pine wood, at least at the genus level, was the reason for their travel to Newfoundland.

\section{Biogeography of pine wood in Labrador and Newfoundland}

Southern Labrador is dominated primarily by three ecoregions: 1) Coastal Barrens; 2) Forteau Barrens; and 3) the Mid Boreal Forest (Government of Newfoundland and Labrador 2007). Because of the cold Labrador Current and the shallow soil in the outer bays and headlands of the Coastal Barrens ecoregion from Okak to Battle Harbour, the land resembles Alpine tundra with lichens, ericaceous shrubs, and tuckamore (shrub spruce) dominating the landscape. The more sheltered valleys harbour stands of small black spruce with a lichen understory. The Forteau Barrens ecoregion in the far south, facing the Strait of Belle Isle, is dominated by scrubby black spruce, barrens, and poorly drained peatlands. The most productive ecoregion is the Mid Boreal Forest Ecoregion. The valleys of the inner bays consist of stands of black spruce and balsam fir with a lichen or feathermoss understory. Some white birch and trembling aspen are also found in this region with Kalmia heaths forming much of the highland areas (ibid.). The southward-flowing Labrador Current prevents any movement of driftwood (indigenous plant/tree species) from Newfoundland to Labrador.

Let us now review the tree species that grow on the island of Newfoundland but not in Labrador. A number of species reach their northern limit on the island at the southern boundary of the Great Northern Peninsula ecoregion (Damman 1983: 165;

5 Except for the Qinngua Valley on the southern tip of the island, where the main species are downy birch (Betula pubescens) and leaf willow (Salix glauca). 
Meades and Moores 1989: 6-6). There are 21 tree species in the Province of Newfoundland and Labrador (Fernald 1970; Government of Newfoundland and Labrador 2015), five of which do not occur in Labrador (Ryan 1978), namely, red maple (Acer rubrum), black ash (Fraxinus nigra), chokecherry (Prunus virginiana), white pine (Pinus strobus), and red pine (Pinus resinosa) (Figure 1). Several woody shrubs- willows (Salix spp.), mountain maple (Acer spicatum), and pear berries (Amelanchier spp.) - are also serious candidates for manufacture of arrows and darts, but they also grow in Labrador (ibid.: 57, 69). Consequently, none of them are the species being referred to by the Inuit in their 1765 search for arrow shaft wood.

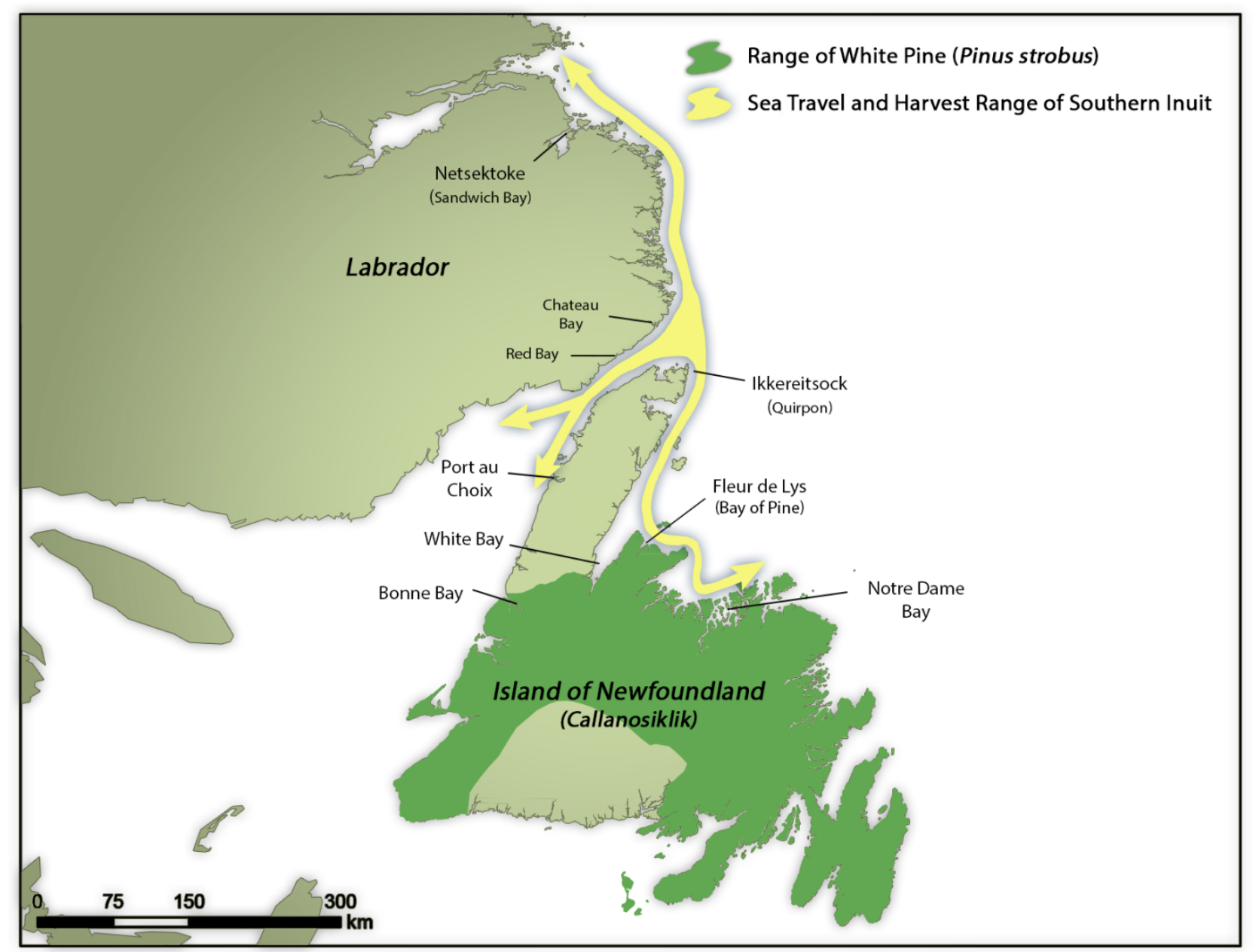

Figure 1. Range of the white pine (Pinus strobus) and travel and harvest range of historic Inuit. Place names include some Inuttitut toponyms. Map created by Resource Innovations.

When travelling down the coasts of Newfoundland in the historic period, Inuit primarily went down the northeast coast as far south as Fogo and the west coast as far south as Port au Choix ${ }^{6}$ (Martijn 2009: 67). Therefore, two of the five species can be eliminated from the list of possible candidates. Red maple (Acer rubrum) and black ash (Fraxinus nigra) do not grow on the northeast coast of Newfoundland or within the Great Northern Peninsula ecoregion (Ryan 1978: 27, 36). The three other species-

6 There is one reference to Inuit travelling on the west coast of Newfoundland as far south as St. George's Bay. This source is doubted by Martijn (2009: endnote 4). 
chokecherry (Prunus virginiana), red pine (Pinus resinosa), and white pine (Pinus strobus) - do not grow in the Great Northern Peninsula ecoregion and are absent generally south of a line drawn from Bonne Bay on the west coast to White Bay on the northeast coast (Figure 1). Of these three remaining candidates, the two species of pine are the most likely ones for wood to make arrows and darts. The last remaining candidate - chokecherry (Prunus virginiana) - is unlikely, since local (Newfoundland) trees and shrubs of this species have twisted boles unsuitable for arrow making.

\section{Evidence of Inuit travel to Newfoundland}

A Late Dorset site on the Greenland side of Smith Sound (High Arctic) contained a relatively large quantity of white pine (Pinus strobus) (Christensen 1999: Table 8 in Alix 2009a: 199). As Claire Alix (ibid.) points out, "The pine was also found at Skraeling Island [...]. Christensen (1999: 75) suggested that other sources of wood than driftwood should be envisioned in order to explain the presence of Pinus sec. strobus, such as exchange with southern regions (e.g., Labrador, where white pine [Pinus strobus] grows)." From all available sources, there is no indication that white pine grows, or has grown, in Labrador. However, it is a relatively short distance (80 nautical miles) to pine stands on the island of Newfoundland.

Inuit travel in the 17th and 18th centuries on the Labrador Atlantic coast appears to have resulted in three different types of encounters: 1) raiding of unoccupied European sites (Hiller 1967: 30; Pope, this volume); 2) conflicts with some groups of Europeans (Martijn 2009: 72-79; Mitchell 2013: 320-330; Pope, this volume); and 3) sporadic highly guarded trade (Martijn 2009: 70, 75). Martijn and Dorais (2001: 323) concede that "although access to local subsistence resources probably constituted one attraction, the Inuit seem to have been drawn initially to the Northern Peninsula primarily by opportunities to engage in bartering activities with the French and Basque fishermen [...]." If Labrador Inuit were in search of wood resources, they would do as Inuit did in other parts of the Arctic and Subarctic. Inuinnait (Copper Inuit), for example, travelled regularly to the treeline and into the forests near Great Slave Lake to obtain wood for their use and trade (Alix 2009a: 190, 2012: 17).

There is some empirical evidence of Inuit presence as far south as Notre Dame Bay on Newfoundland (Figure 1), which is well into the range of red and white pine stands noted above. A quote from a recent paper by Marianne Stopp emphasizes this point:

Pitt features in low elevation cobble beaches in western Notre Dame Bay, traditionally used for preserving seal meat and pokes of seal oil (a trade item), are archaeological evidence tied to Inuit presence on the island of Newfoundland (Stopp 2006), while sod houses tested at Degrat Island and Quirpon are also of Inuit origin (Auger 1991). Identical features are found all along the coast of southern Labrador, and point to a broad-based Inuit presence not only in summer but also in winter (Stopp 1994, 2002, 2013b) (Stopp 2014: 5). 
Stands of clear straight pines in the area of Notre Dame Bay and a little further west would have surely presented Inuit with ample opportunity to obtain good arrow shaft material (Figure 1).

Until 1764 and the excursions of a visiting Moravian missionary, Jens Haven (Lysaght 1971: 188), there was no contact between Inuit and Europeans who were fluent in Inuktitut and could communicate well with the Inuit. Up until that time, trade was limited and used a pidgin language associated with the activity at hand (Bakker 1991: 7-11). Consequently, there is no primary European record of travel, foraging, or ethnological observations by Inuit individuals prior to their contact with Moravians in 1764. The Inuit perspective is lost to history.

The first written record identifying Inuit on Newfoundland refers to Quirpon (located at the tip of the Petit Nord on the Great Northern Peninsula, Figure 1) in 1588 (La Morandière 1962: 19 in Martijn and Dorais 2001: 323). In 1694, Captain Wheeler of the British Navy described Inuit presence in the summer months as "numerous" and "at utter defiance" of the French (Marshall 1996: 53). As early as 1609, the French requested armed vessels to protect their fishermen from Inuit attacks. Inuit were known to have traded sporadically as far south as Port au Choix on the western side of the Great Northern Peninsula and into Notre Dame Bay on the eastern side (ibid.: 53). In 1701, Commander Graydon reported the presence of Inuit between Croque and Notre Dame Bay (Howley 1915: 35; Marshall 1996: 54).

By 1771, Inuit were referring to the island of Newfoundland as Callanosiklik, ${ }^{7}$ which Pigott (2010: 20) has interpreted to mean '[the place which is] in the process of having white people' and which, according to him, indicates prior knowledge of Newfoundland before the arrival of Europeans. The toponym Ikkarumiklua (meaning 'enormous shoals') was also used to describe Newfoundland but may have been a very local term for shoals at the extremity of the Great Northern Peninsula and not for the entire island, if, in fact, Inuit knew it to be an island (Martijn and Dorais 2001: 325). Many of the conflicts with the transitory French fishing fleets in the 17th century took place on the eastern side of the Petit Nord on Newfoundland's Great Northern Peninsula (Pope, this volume). Shawnadithit, a Beothuk woman residing primarily in the Bay of Exploits, had knowledge of the Labrador Inuit. Whether that knowledge was due to contact with Inuit is simply unknown (Marshall 1996: 55). It is the opinion of Martijin and Dorais (2001: 325) that "Between 1580 and ca. 1800, their [Inuit] known range extended only as far southward as St. George's Bay, on the west coast, and to Fogo Island, on the north-east coast."

The range of Inuit travel to Newfoundland in the three centuries under scrutiny may have been, in part, driven by migratory seal herds (Stopp 2014: 5), and it conveniently overlapped the range of white and red pine on the island of Newfoundland. Given that southern Inuit in Labrador ubiquitously use "country food" at present (Mitchell 2014: 215-240), including all seal species, their ancestors would

$7 \quad$ See also Stopp (2014: 9) for a slightly different spelling. 
have certainly chased seal herds with several million animals gathering and migrating yearly. The harp seal herd enters northern Labrador waters on the newly formed Arctic ice in mid- to late October and migrates as far as the Strait of Belle Isle by midDecember (Fisheries and Oceans Canada n.d.). The herd then splits into two segments with one third of the group migrating into the Gulf of St. Lawrence and the remainder migrating along the northeast coast of Newfoundland. During January and February, the population disperses widely for feeding. Pregnant females haul out on to the pack ice in late February and March for whelping (birth). In spring (April/May), the herds follow the receding pack ice north to Baffin Bay and Greenland. This migration pattern greatly resembles what we now know about the travel routes of Labrador Inuit (Figure 1). Since some groups in southern Labrador were variously called "Netsetmuit" (sealhunting people) (Speck 1936: 322) and since the winter homes of some groups were at "Netsektok" (place of the seal) (Rollmann 2010: 1), it is very likely that Inuit travelled to northeastern Newfoundland in pursuit of these large seal herds and, like northern foragers in general, discovered and utilized other local resources, such as pine wood.

\section{The Red Bay arrow shafts}

In a conversation with James Tuck in June 2010, I learned that in 1984 he and his team had uncovered several Inuit artefacts, including what were assumed to be pinewood arrow shafts, at Twin Island 3 (EkBc-07), a 16th-century Basque site at Red Bay, Labrador (see also Tuck 1984). I subsequently examined four arrow shafts from that site at The Rooms Provincial Museum (St John's, Newfoundland). Figures 2 through 5 show the arrow shaft fragments excavated from the Twin Island 3 site, and roughly dated with other Inuit objects to the late 16th century (Tuck 1984: 224). They are characterized by widened proximal ends with flattened $\mathrm{V}$-nocks, are similar to other arrow shafts from Thule sites across the Arctic (Alix et al. 2012: 108), and are typical of Inuit craftsmanship, being found nowhere else in the world (Mason 1894: 650).

The Red Bay shafts look morphologically similar to those collected from northern Labrador by Hawkes (1916: Plate No. XVI), which had an average shaft length of 40 $\mathrm{cm}$ and unknown species provenance. From outside Labrador, the shaft specimens collected by Lucien Turner at Whale River, Ungava, (item no 90138, Smithsonian Institution, see Mason 1894: Plate LVIII) also look very similar to the Red Bay arrow shafts, with the characteristic flattened nock and average length of $63 \mathrm{~cm}$. Arrow specimens collected by Ludwig Kumlien (item 78A00081, Smithsonian Institution) on Baffin Island are similar to the Red Bay shafts and are comparable in length at $44 \mathrm{~cm}$. Although several of these collections are claimed to have pine wood specimens; no positive identification has ever been made.

Only one specimen from Red Bay (no 918) had all of the determinative characteristics for Inuit arrow shafts. Considering that these shaft segments were all incomplete, it is understandable that not all characteristics were displayed by each one (Table 1). 


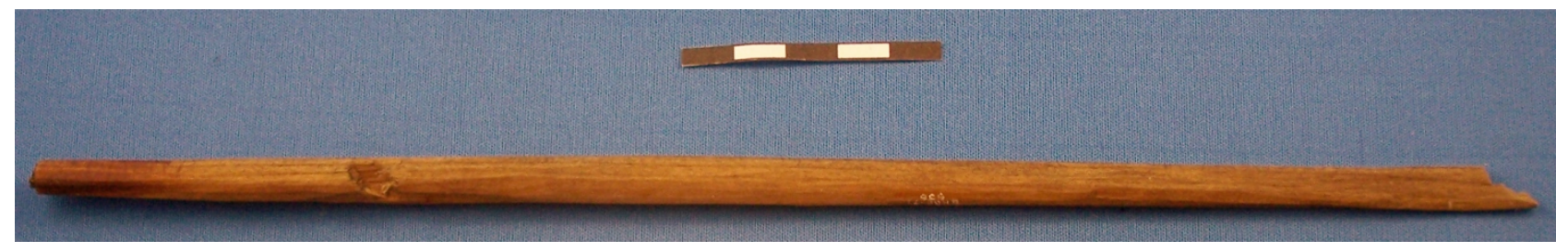

Figure 2. Arrow shaft segment from Twin Island 3 site (EkBc-07), Red Bay, Labrador. Item no 636, The Rooms Provincial Museum. Scale in cm. Photo: Greg Mitchell. Courtesy of The Rooms Provincial Museum, St. John's.

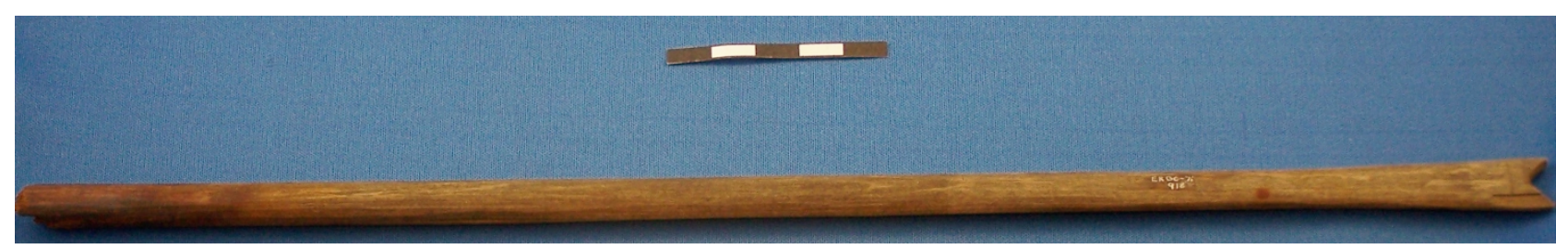

Figure 3. Arrow shaft segment from Twin Island 3 site (EkBc-07), Red Bay, Labrador. Item no 918, The Rooms Provincial Museum. Scale in cm. Photo: Greg Mitchell. Courtesy of The Rooms Provincial Museum, St. John's.

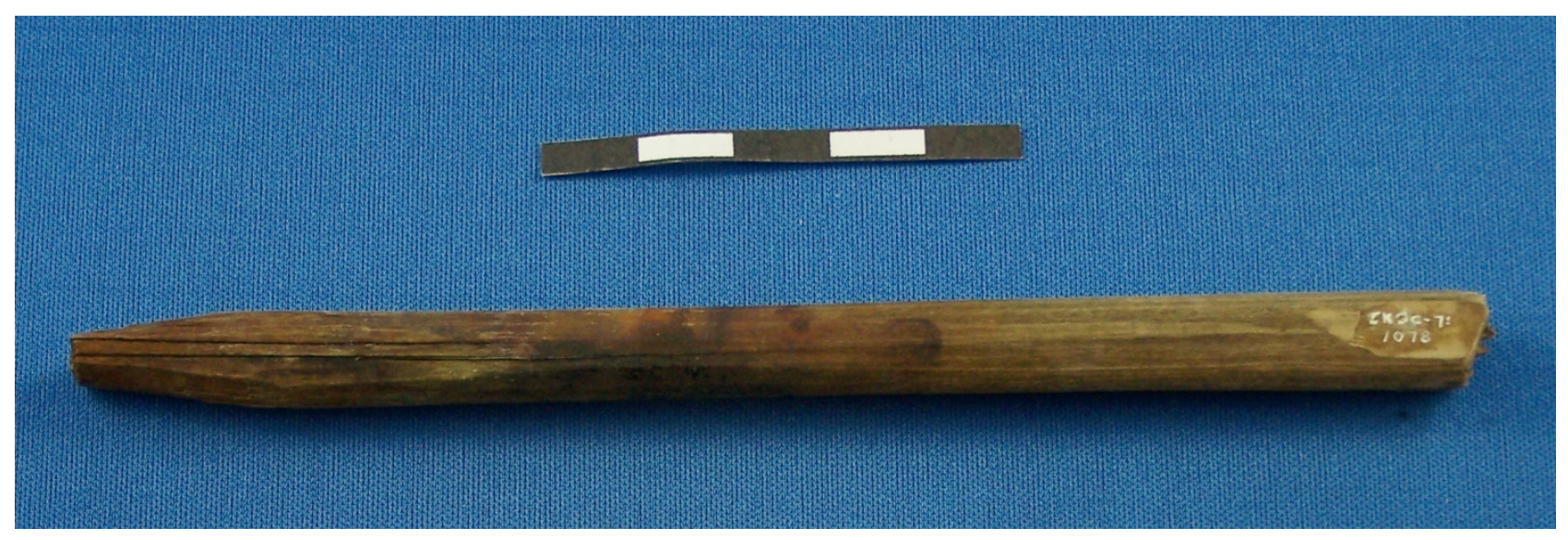

Figure 4. Arrow shaft segment from Twin Island 3 site (EkBc-07), Red Bay, Labrador. Item no 1078, The Rooms Provincial Museum. Scale in cm. Photo: Greg Mitchell. Courtesy of The Rooms Provincial Museum, St. John's.

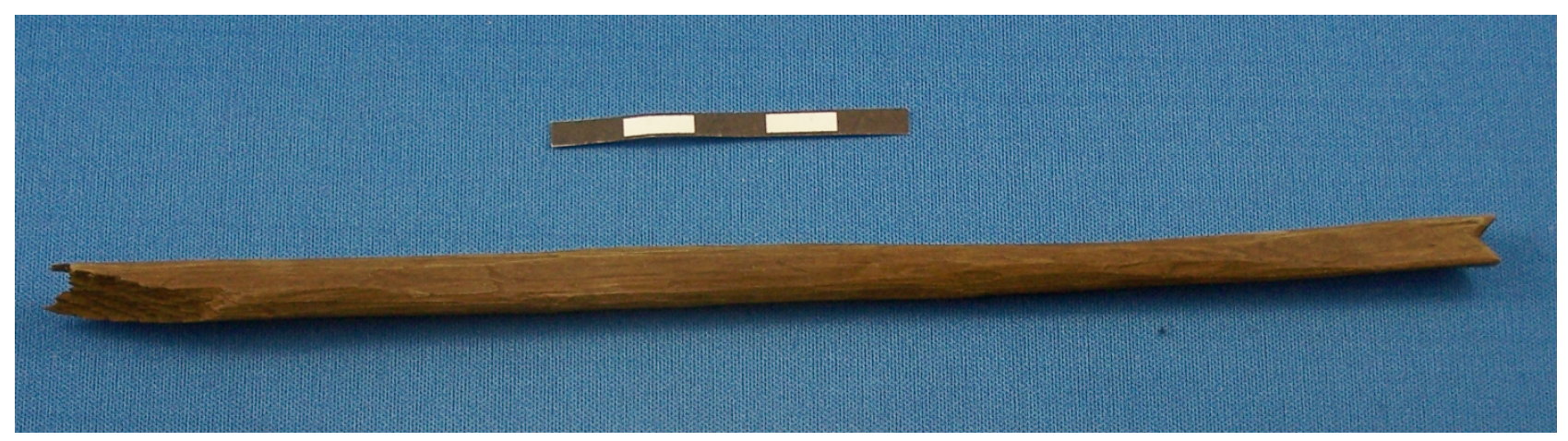

Figure 5. Arrow shaft segment from Twin Island 3 site (EkBc-07), Red Bay, Labrador. Item no 1244, The Rooms Provincial Museum. Scale in cm. Photo: Greg Mitchell. Courtesy of The Rooms Provincial Museum, St. John's. 
Table 1. The four arrow shaft specimens from location EkBc-07 at Red Bay, Labrador.

\begin{tabular}{|c|c|c|c|c|c|}
\hline $\begin{array}{c}\text { Shaft } \\
\text { segment no. }\end{array}$ & $\begin{array}{c}\text { Length } \\
(\mathbf{c m})\end{array}$ & Shaft taper & $\begin{array}{c}\text { Nock } \\
\text { flattening }\end{array}$ & Distinct 'V' string nock & $\begin{array}{c}\text { Fletching } \\
\text { marks }\end{array}$ \\
\hline & & & & & \\
\hline 636 & 31.0 & Present & Present & Indeterminate & Present \\
\hline 918 & 35.0 & Present & Present & Present & Present \\
\hline 1078 & 14.5 & Indeterminate & None & None & Present \\
\hline 1244 & 25.0 & Present & Present & Present & None \\
\hline
\end{tabular}

\section{Methodology}

To positively identify the species of wood in these shaft segments, The Rooms Provincial Museum granted me permission to obtain a small section of a shaft segment for microscopic examination. Segment no. 1244 was chosen as the source and a $3 \mathrm{~mm} \mathrm{x}$ $3 \mathrm{~mm} \times 10 \mathrm{~mm}$ specimen was removed from the shaft using a razor blade. The specimen was immersed in a dilute solution of dish detergent for two days prior to sectioning. Using a hand sectioning method, Henry Mann at the Grenfell Biology Herbarium shaved off very thin sections (several microns thick) in transversal, tangential, and radial sections. Approximately 60 sections were then wet-mounted on microscope slides for examination.

A Nikkon Eclipse Ni-U light microscope, with camera attachment, was then used to examine the wet-mounted slides and take photographs of the various sections. Descriptions and keys from the Mount Allison Dendrochronology Lab (Robichaud et al. 2012) were used to determine the species under examination.

\section{Results}

It was almost immediately determined that the specimens were a coniferous softwood. None of the sections displayed pores, typical of hardwood species. From the following characteristics, it was further determined that the species of wood in the shaft segment was balsam fir (Abies balsamea):

1) The transition zone between late and early wood was gradual,

2) There was a total lack of resin canals (Figure 6),

3) Rays were uniseriate (one-cell wide),

4) Ray cross field pits were taxodioid (small with apertures broadly elliptical or circular and having a narrow border, Figure 7).

Ray heights were observed to be between 5 and 11 cells deep. Taxodioid pits were a little difficult to observe but were distinguishable at a 400x magnification by focusing up and down within the field (Figure 7). 




Figure 6. Transverse section (photo A-9-100) of arrow shaft specimen no. 1244 (balsam fir, Abies balsamea) showing a lack of resin canals and a gradual transition zone of early to late wood. 100x magnification. Photo: Henry Mann.

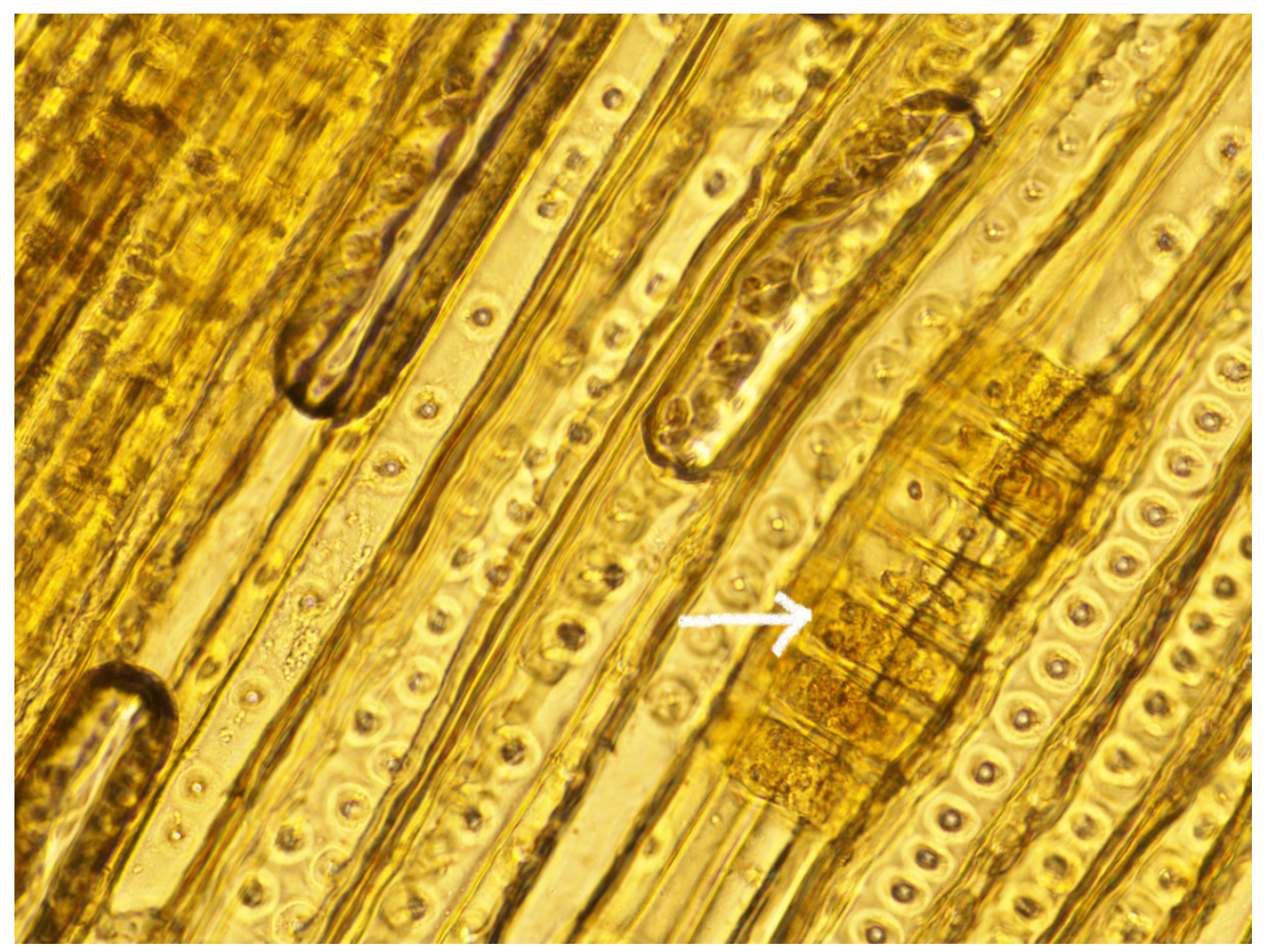

Figure 7. Tangential section (photo B-6-400a) of arrow shaft specimen no. 1244 (balsam fir, Abies balsamea) showing taxodioid pits (see arrow) within the uniseriate parenchyma rays. 400x magnification. Photo: Henry Mann. 


\section{Discussion and conclusion}

The Thule people had a "deep knowledge of wood quality and wood working techniques and [...] in the migration east, they met with new conditions of wood availability to which they rapidly adapted" (Alix 2009a: 196). Labrador Inuit, at least in 1798, were described by Captain Ambrose Crofton (1798: 34) from Chateau Bay, in the following terms: "I have observed in the Esquimaux Indians since I met them twenty years ago, its [sic] probable in a short time they will navigate the coast in vessels of their own construction, as I discovered in their Shallop carpenters and shipwright tools of all descriptions." It is clear from this statement that Crofton was impressed by the woodworking abilities of the travelling Inuit.

When analysed, the balsam fir (Abies balsamea) arrow shaft segments from the late 16th-century Basque site at Twin Island 3 (EkBc-07), Red Bay, in southern Labrador were found, by all characteristics, to be of Inuit manufacture. Balsam fir is abundant in Labrador, and yet two centuries later at Chateau Bay, merely $30 \mathrm{~km}$ north of Red Bay, Inuit were persistent in their attempts to get to the island of Newfoundland for shaft wood. I have proposed that the desired wood was pine, which was located in the central Newfoundland ecoregion approximately 90 nautical miles to the south of Red Bay and Chateau Bay.

Though forbidden to do so by the British Navy, Inuit continued during the summer and autumn of 1765, and in later times, to visit the island of Newfoundland to get wood for arrows and darts, a practice that may be quite telling of former harvesting activities, conflicts, and expansion of trade patterns spanning the late 16th to late 18th centuries. Amerindians (specifically, Beothuk in Newfoundland) used pine wood for arrow shafting during this time period. If the wood sought by Indigenous people had to be easily cleaved, straight-grained, strong, light, and workable, and if those requirements could be met with balsam fir from Labrador, then why did Inuit show excessive desire to obtain their arrow shaft materials from the island of Newfoundland? These materials, as they claimed, did not grow in Labrador. As I have argued, the sought-after species was one, or both, of the two pines growing in central Newfoundland (Pinus strobus or Pinus resinosa).

Specimens of pines, possibly from Newfoundland, have been found at archaeological sites in northern Labrador (Fitzhugh et al. 2006: 168) and in the Eastern Arctic (Alix 2009b; 158, 159). Arrow shafts from Baffin Island and Ungava, collected in the 19th century for museum collections, have been attributed to pine wood (Mason 1894) but this remains to be confirmed. Further microscopic examinations of extant museum and archaeological collections will help to answer the questions brought forward in this paper. 


\section{Acknowledgments}

I especially would like to thank Hans Rollmann for his tremendous help in this and in all my projects. Henry Mann was invaluable in helping with specimen preparation and identification. I would like to thank Lisa Rankin for guidance, support, and expert help. In fact, I would thank all my colleagues from the SSHRC (Social Sciences and Humanities Research Council of Canada)-CURA project "Understanding the Past to Build the Future." It has been for me a genuine learning experience for five years, without attending classes, or paying any tuition! My gratitude goes to staff at The Rooms Provincial Museum and Memorial University during my search for artefacts; Maria Lear, Kevin McAleese, Elaine Anton, and Lori Temple. I also thank the other experts who responded to my bothersome queries with regard to this paper and on related topics, as well as William Fitzhugh, Peter Pope, Rainer Baehre, Claire Alix, Peter Whitridge, Susan Kaplan, Scott Neilsen, Tim Rast, and the many others whom I may have forgotten. Thank you all.

\section{Archival sources}

\section{CROFTON, Ambrose}

1798 Report on a Cruise around Newfoundland and along Labrador, UK National Archives, Colonial Office 194 Series, vol. 40: 17-34, microfilm on file, Corner Brook, Memorial University of Newfoundland, Grenfell Campus, Ferriss Hodgett Library.

DRACHARDT, Christen Larsen

1770 To Bruder Joseph [August Gottlieb] Spangenberg, Chateau Bay, 20 September 1770, R.15.K.a.5.6, Herrnhut, Unity Archives.

IRVING, Joseph

1772 Masters Logs, Public Record Office, Admiralty Series 52, folio 1387, HMS Otter Master's Logs 1768-1773, Log Book no. 9, Kew, UK National Archives.

\section{PALLISER, Sir Hugh}

1765 Series of documents relating to the Labrador Coast, UK National Archives, Colonial Office 194 Series, vol. 16: 225-245, microfilm on file, Corner Brook, Memorial University of Newfoundland, Grenfell Campus, Ferriss Hodgett Library.

REYNOLDS, R.C.

1786 Account of the French Fisheries for 1786, UK National Archives, Colonial Office 194 Series, vol. 21: 39, microfilm on file, Corner Brook, Memorial University of Newfoundland, Grenfell Campus, Ferriss Hodgett Library. 


\section{References}

\section{ANONYMOUS}

1761 Plantation News, The Ipswich Journal, December 26, 1198: 2, British Newspaper Archive (http://www.britishnewspaperarchive.co.uk/).

1762 A State of the Newfoundland Fishery, with a Plan Proposed for Excluding the French from that Trade, Caledonian Mercury, 30 August, 6359: 1, British Newspaper Archive (http://www.britishnewspaperarchive.co.uk).

ALIX, Claire

2009a Persistence and Change in Thule Wood Use, AD 1100-1450, in Herbert Maschner, Owen Mason and Robert McGee (eds), The Northern World AD 900-1400, Salt Lake City, University of Utah Press: 179-205.

2009b Driftwood, Timber and Shrubs! Wood Used by Ruin Islander Thule at Skraeling Island, Eastern Ellesmere Island, Canada, in Bjarne Grønnow (ed.), On the Track of the Thule Culture from Bering Strait to Eastern Greenland, Copenhagen, Publications from the National Museum Studies in Archaeology and History, 15: 149-165.

2012 Introduction: Arctic Peoples and Wood, Études/Inuit/Studies, 36(1): 15-22..

ALIX, Claire, Gregory HARE, Thomas ANDREWS and Glen MACKEY

2012 A Thousand Years of Lost Hunting Arrows: Wood Analysis of Ice Patch Remains in Northwestern Canada, Arctic, 65, Suppl. 1: 95-117.

BAKKER, Peter

1991 Trade Languages in the Strait of Belle Isle, Journal of the Atlantic Provinces Linguistic Association, 13: 1-20.

CAMPBELL, Neil A. and Jane B. REECE

2005 Biology: Seventh Edition, New York, Pearson Benjamin Cummings.

CARTWRIGHT, F.D. (ed.)

1969[1826] The Life and Correspondence of Major Cartwright, New York, Augustus M. Kelly.

\section{CARTWRIGHT, George}

1792 Journal of Transactions and Events during a Residence of Nearly Sixteen Years on the Coast of Labrador, vol. 1, Newark, Allin and Ridge.

CHRISTENSEN, $\mathrm{K}$.

2014 Appendix 2: Wood Determination, in M. Appelt and H.C. Gulløv, Late Dorset in High Arctic Greenland. Final Report on the Gateway to 
Greenland Project, Copenhagen, Danish National Museum and Danish Polar Center: 73-78.

CROMPTON, Amanda

2014 The Many Habitations of Pierre Constantin: The French Presence in Southern Labrador in the Early Eighteenth Century, in John C. Kennedy (ed.), History and Renewal of Labrador's Inuit-Métis, St. John's, Memorial University of Newfoundland, ISER Books: 94-121.

DAMMAN, A.W.H.

1983 An Ecological Subdivision of the Island of Newfoundland, in G. Robin South (ed.), Biogeography and Ecology of the Island of Newfoundland, The Hague, Dr W. Junk Publishers: 163-205.

DYKE, Arthur, John ENGLAND, Erk REIMNITZ and Hélène JETTÉ

1997 Changes in Driftwood Delivery to the Canadian Arctic Archipelago: The Hypothesis of Postglacial Oscillations of the Transpolar Drift, Arctic, 50(1): $1-16$.

ELLIOT, Deborah and Susan SHORT

1979 The Northern Limit of Trees in Labrador: A Discussion, Arctic, 32(3): 201206.

FERNALD, Merritt Lyndon

1970 Gray's Manual of Botany, 8th edition, New York, Van Nostrand Reinhold Company.

\section{FISHERIES AND OCEANS CANADA}

n.d. UnderwaterWorld - The Harp Seal, Fisheries and Oceans Canada, Science and Research Publications (online at http://www.dfo-mpo.gc.ca/science/ publications/uww-msm/articles/seal-phoque-eng.htm ).

FITZHUGH, William W., Anna HERZOG, Sophia PERDIKARIS and Brenna McLEOD

2011 Ship to Shore: Inuit, Early Europeans, and Maritime Landscapes in the Northern Gulf of St. Lawrence, in Ben Ford (ed.), The Archaeology of Maritime Landscapes, New York, Springer: 99-128.

FITZHUGH, William W., Richard JORDAN, James ADOVASIO and Dosia LAEYENDECKER

2006 Cordage and Wood from the Avayalik Dorset Site in Northern Labrador, in J. Arneborg and B. Grønnow (eds), Dynamics of Northern Societies: Proceedings of the SILA/NABO Conference on Arctic and North Atlantic Archaeology, Copenhagen, May 10-14, 2004, Copenhagen, Publications from the National Museum, Studies in Archaeology and History, 10: 153177. 


\section{GOVERNMENT OF NEWFOUNDLAND AND LABRADOR}

2007 Map of Ecoregions of Newfoundland and Labrador, Deer Lake, Government of Newfoundland and Labrador, Department of Environment and conservation, Parks and Natural Areas Division (online at: http://www.env.gov.nl.ca/env/parks/maps/ecoregions_nf_lab.pdf).

2015 List of Tree Species in Newfoundland and Labrador, Government of Newfoundland and Labrador website (http://www.faa.gov.nl.ca/forestry/ our_forest/treespecies/index.html).

GRØNNOW, Bjarne

2012 An archaeological reconstruction of Saqqaq bows, darts, harpoons, and lances, Études/Inuit/Studies, 36(1): 23-48.

HAWKES, E.W.

1916 The Labrador Eskimo, Ottawa, Geological Survey, Memoir 91, Anthropological Series 14.

HELLMAN, Lena, Wally TEGAL, Olafur EGGERTSON, Fritz Hans SCHWEINGRUBER, Robert BLANCHETTE, Alexander KIRDYANOV, Holger GARTNER and Ulf BUNTGEN

2013 Tracing the origin of Arctic driftwood, Journal of Geophysical Research, 8: $1-9$.

HILLER, James

1967 The Foundation and the Early Years of the Moravian Mission in Labrador, 1752-1805, M.A. thesis, Memorial University of Newfoundland, St. John's.

HOWLEY, J.P.

1915 The Beothuks or Red Indians, Cambridge, Cambridge University Press.

JORDAN, Richard H. and Susan A. KAPLAN

1980 An Archaeological View of the Inuit/European Contact period in Central Labrador, Etudes/Inuit/Studies, 4(1-2): 35-46.

KAPLAN, Susan A.

1980 Neo-Eskimo Occupations of the Northern Labrador Coast, Arctic, 33(3): 646-658.

2012 Labrador Inuit Ingenuity and Resourcefulness: Adapting to Complex Environmental, Social and Spiritual Environment, in David Natcher, Lawrence Felt and Andrea Procter (eds.), Settlement Subsistence and Change among the Labrador Inuit, Winnipeg, University of Manitoba Press, 15-42. 


\section{KELVIN, Laura and Lisa K. RANKIN}

2014 The Inuit-Métis of Sandwich Bay: Oral Histories and Archaeology, in John C. Kennedy (ed.), History and Renewal of Labrador's Inuit-Métis, St. John's, Memorial University of Newfoundland, ISER Books: 120-134.

KENNEDY, John C.

2009 Two Worlds of Eighteenth Century Inuit, in Hans Rollmann (ed.), Moravian Beginnings in Labrador: Papers from a Symposium held in Makkovik and Hopedale, St. John's, Newfoundland and Labrador Studies, Occasional Publication, 2: 23-36.

LA MORANDIÈRE, Charles de

1962 Histoire de la pêche française de la morue dans l'Atlantique septentrionale, vol. 1, Paris, G.P. Maisonneuve et Larose.

\section{LANTEIGNE, Robert}

2014 Le mythe Thévenard et les conflits entre pêcheurs malouins et les Inuit au Petit Nord de 1749 à 1765, Le Manuscrit, Revue étudiante du Département d'Histoire de l'UQAM: Conflit, espace et religion, automne 2014 (online at: http://www.revuelemanuscrit.uqam.ca/).

LYSAGHT, A.M.

1971 Joseph Banks in Newfoundland and Labrador, 1766: His Diary, Manuscripts and Collections, Berkeley and Los Angeles, University of California Press.

MARSHALL, Ingeborg

1996 A History and Ethnography of the Beothuk, Montreal and Kingston, McGillQueen's University Press.

MARTIJN, Charles A.

2009 Historic Inuit Presence in Northern Newfoundland, Circa 1550-1800 CE, in David L. Keenleyside and Jean-Luc Pilon (eds.), Painting the Past with a Broad Brush: Papers in Honour of James Valliere Wright, Gatineau, Canadian Museum of Civilization, Mercury Series, 170: 65-101.

MARTIJN, Charles A. and Louis-Jacques DORAIS

2001 Eighteenth Century Innu (Montagnais) and Inuit Toponyms in the Northern Peninsula of Newfoundland, Newfoundland Studies, 17(2): 319-330.

MASON, Otis Tufton

1894 North American Bows, Arrows, and Quivers, Washington, Government Printing Office, Smithsonian Report for 1893: 631-679. 
McGHEE, Robert

2009 When and Why Did the Inuit Move to the Eastern Arctic?, in Herbert Maschner, Owen Mason and Robert McGhee (eds), The Northern World AD 900-1400, Salt Lake City, The University of Utah Press: 155-163.

MOORES, Len and Bill MEADES

1989 Forest Site Classification Manual, St. John's, Government of Newfoundland, Forest Resource Development Agreement, FRDA Report, 3.

MITCHELL, Greg

2013 The Inuit of Labrador and their Conflicts with Europeans, to 1767, in Peter E. Pope and Shannon Lewis-Simpson (eds.), Exploring Atlantic Transitions, Woodbridge, Boydell Press, The Society for Post-Medieval Archaeology Monograph, 8: 320-330.

2014 "We Don't Have Any Klick or Spam in the House - How About a Piece of Boiled Salmon for Lunch?": Country Food in NunatuKavut, in John C. Kennedy (ed.), History and Renewal of Labrador's Inuit-Métis, St. John's, Memorial University of Newfoundland, ISER Books: 215-240.

MURPHY, Phoebe and Lisa K. RANKIN

2014 Exploring the Communal House Phase in Sandwich Bay, in John C. Kennedy (ed.), History and Renewal of Labrador's Inuit-Métis, St. John's, Memorial University of Newfoundland, ISER Books: 62-74.

PIGOTT, Paul

2010 Linguistic Analysis of the Richardson Word List: Final Report, unpublished report on file, Happy Valley-Goose Bay, Library of NunatuKavut Community Council.

RAMSDEN, Peter and Lisa K. RANKIN

2013 Thule Radiocarbon Chronology and its Implications for Early InuitEuropean Interaction in Labrador, in Peter E. Pope and Shannon LewisSimpson (eds.), Exploring Atlantic Transitions, Woodbridge, Boydell Press, The Society for Post-Medieval Archaeology Monograph, 8: 299-309.

RANKIN, Lisa K.

2013 Role of the Inuit in the European Settlement of Sandwich Bay, Labrador, in Peter Pope with Shannon Lewis-Simpson (eds), Exploring Atlantic Transitions: Archaeologies of Transience and Permanence in New Found Lands, Woodbridge, Boydell Press, The Society for Post-Medieval Archaeology Monograph, 8: 310-319.

2014 Inuit Settlement on the Southern Frontier, in John C. Kennedy (ed.), History and Renewal of Labrador's Inuit-Métis, MUN, St. John's, Institute of Social and Economic Research: 38-61. 
RANKIN, Lisa K., Matthew BEAUDOIN and Natalie BREWSTER

2012 Southern Exposure: The Inuit of Sandwich Bay, in David Natcher, Lawrence Felt, and Andrea Procter (eds.), Settlement Subsistence and Change Among the Labrador Inuit, Winnipeg, University of Manitoba Press: 61-84.

ROBICHAUD, Andre, James EHRMAN, Bryan MOOD and Colin LAROQUE

2012 Description and wood identification of native coniferous tree species in the Maritimes from dendrochronological material, Sackville, Mount Allison Dendrochronology Laboratory, MAD Lab Report 2012-17.

ROLLMANN, Hans J.

2010 Inuit Mobility to and from Southern Labrador in the Hopedale Moravian Diaries and Church Book, contract research for the Labrador Métis Nation, Happy Valley-Goose Bay, report on file at the Library of NunatuKavut Community Council.

2011 "So fond of the pleasure to shoot": The Sale of Firearms to Inuit on Labrador's North Coast in the Late Eighteenth Century, Newfoundland and Labrador Studies, 26(1): 5-24.

RYAN, Glen

1978 Native Trees and Shrubs of Newfoundland and Labrador, Parks and Natural Areas Division, St. John's, Government of Newfoundland.

SMART LABRADOR INITIATIVE

2004 Labrador Inuttut Dictionary, Virtual Museum of Labrador web site (http://www.labradorvirtualmuseum.ca/home/inuttut_dictionary.htm).

SPECK, Frank G.

1936 Inland Eskimo Bands of Labrador, in Robert Lowie (ed.), Essays in Anthropology presented to Alfred Louis Kroeber in celebration of his sixtieth birthday, Berkeley, University of California Press, New York, Freeport, Books for Libraries Press: 313-330.

STOPP, Marianne P.

2002 Reconsidering Inuit presence in southern Labrador, Études/Inuit/Studies, 26(2): 71-106.

2014 The Complete Inuttitut Vocabulary of William Richardson, Memorial University, St. John's, NL, Regional Language Studies...Newfoundland, 25: $1-22$.

STOPP, Marianne P. (ed.)

2008 The New Labrador Papers of Captain George Cartwright, Montreal and Kingston, McGill-Queen's Press. 
SUTHERLAND, Patricia D.

1999 Strands of Culture Contact, in Martin Appelt, Joel Berglund and Hans Christian Gullov (eds), Identities and Cultural Contacts in the Arctic, Proceedings from a Conference at the Danish National Museum, Copenhagen, The Danish National Museum and Danish Polar Center: 159169.

TAYLOR, J. Garth

1972 Eskimo Answers to an Eighteenth Century Questionnaire, Ethnohistory, 19(2): 135-145.

TUCK, James A.

1984 Excavations at Red Bay, Labrador, in Jane Sproull Thomson and Callum Thomson (eds), Archaeology in Newfoundland and Labrador 1984, St. John's, Government of Newfoundland and Labrador, Historic Resources Division, Annual Report 5: 224-247.

\section{WHITRIDGE, Peter}

2102 Invented Places: Environmental Imaginaries and the Inuit Colonization of Labrador, in David Natcher, Lawrence Felt, and Andrea Procter (eds), Settlement Subsistence and Change Among the Labrador Inuit, Winnipeg, University of Manitoba Press: 43-60. 